\title{
Instructional design for live online teaching: using mnemonics to support a UDL-centred approach
}

\author{
Kevin L. Merry \\ De Montfort University
}

Keywords: universal design for learning; remote virtual teaching; synchronous learning and teaching; Covid-19

\section{The challenge}

Covid-19 has caused an abrupt shift in the way that higher education teaching staff design and deliver their teaching. Stemming from an emergency need to keep things going during the spring 2020 lockdown in the UK, learning shifted online, initiating the mass adoption of remote virtual teaching. For many, teaching live sessions online was a novel experience, with few staff possessing the experience or skills to deliver effective online education (Kozimor, 2020). As such, ensuring that staff possess the capability to deliver live online sessions competently and in a consistent fashion, has been of principle concern for academic developers during the pandemic.

In 2016, De Montfort University (DMU) in the UK adopted Universal Design for Learning (UDL) as its institution-wide approach to learning, teaching and assessment due to its considerable learner diversity. For example, approximately 54\% of DMU students come from a Black, Asian and Minority Ethnic (BAME) background, and there are more than 3,000 international students representing more than 130 countries. Furthermore, around $20 \%$ of students have a declared disability. As such, a long-standing institutional priority has been the need to ensure an accessible and inclusive learning experience for its diverse community of learners. Covid-19 has increased the importance of this priority.

Central to the adoption of UDL at DMU has been an approach to instructional design that blends the UDL principles of engagement, representation, and action and expression (Rose, 2000), with important pedagogic characteristics including active and interactive learning, collaboration between students, immediate feedback (Schneider et al., 2018) and 
constructive alignment (Biggs, 2011). As such, a key challenge in responding to the pandemic has been to ensure that staff can competently deliver live online teaching sessions that maintain the pedagogic characteristics underpinning the UDL approach described above.

\section{The response}

To ensure that live online teaching sessions reflect the aforementioned pedagogic characteristics, and taking into account the fact that few staff possessed well-developed skills in relation to delivering live online sessions, a quick guide to designing/delivering live online teaching based on the mnemonic PATTERNS? was created. PATTERNS? stands for Pre-work, Alignment, Technology, Teamwork, Engage/Evaluate, Rewind, No barriers, Support and Questions? PATTERNS? was created in response to Covid-19 as a tool for supporting staff to design and deliver live online teaching which possesses the key pedagogic characteristics of the UDL approach. Detail on PATTERNS? can be found in Table 1.

Table 1. The PATTERNS? quick guide to supporting learner mastery during live online virtual learning sessions.

\begin{tabular}{|l|l|}
\hline \multicolumn{2}{|c|}{ Effective learning and teaching happens in PATTERNS? } \\
\hline Pre-work & $\begin{array}{l}\text { - Have you reminded/encouraged your students to engage } \\
\text { with any pre-work including a pre-recorded screencast or } \\
\text { other resource ahead of your live online session? }\end{array}$ \\
\hline Alignment & $\begin{array}{l}\text { - Does your live online session have clear learning outcomes? } \\
\text { - Does it have activities that reflect the outcomes? }\end{array}$ \\
\hline Technology & $\begin{array}{l}\text { - Have you checked that whatever technology you are using is } \\
\text { functioning properly by testing it ahead of the session? }\end{array}$ \\
\hline
\end{tabular}




\begin{tabular}{|c|c|}
\hline & $\begin{array}{l}\text { - Are you aware of any challenges your students may face } \\
\text { with the technology? }\end{array}$ \\
\hline Teamwork & $\begin{array}{l}\text { - Are there opportunities for group work, collaboration and } \\
\text { peer review/feedback in your live online session? }\end{array}$ \\
\hline Engage/Evaluate & $\begin{array}{l}\text { Are there opportunities for: } \\
\text { - } \text { Active learning (e-tivities) } \\
\text { - Self-assessment } \\
\text { - } \text { Choice of activity } \\
\text { - Engagement with multimedia (videos, images etc.) } \\
\text { - Student feedback }\end{array}$ \\
\hline Rewind & $\begin{array}{l}\text { - Is there an opportunity for students to review the session } \\
\text { through a recording, summary notes, a wiki, blog, discussion } \\
\text { forum or other resource? }\end{array}$ \\
\hline No barriers & $\begin{array}{l}\text { - Are your learning resources presented in modifiable formats } \\
\text { and do they conform to inclusive and accessible practices } \\
\text { (font styles and sizes, colours, background colours, images, } \\
\text { use of glossaries where appropriate)? }\end{array}$ \\
\hline Support & $\begin{array}{l}\text { - Have you provided students with your contact details and } \\
\text { details of when and how to contact you for further support } \\
\text { following the session? }\end{array}$ \\
\hline$?$ & $\begin{array}{l}\text { - Are you checking understanding with questioning? } \\
\text { - Are there regular opportunities for student questions? }\end{array}$ \\
\hline
\end{tabular}


Since launching in April 2020, about 1,000 staff have accessed PATTERNS? as a screencast or downloadable quick-guide.

Anecdotal feedback from users has been positive. Specifically, users appeared to benefit from the way in which PATTERNS? enabled them to intentionally include important UDL pedagogic considerations in the design of their live online teaching. Such considerations related to engaging students through collaboration, active and interactive learning, and enabling student choice and autonomy, with users citing the Teamwork and Engage/Evaluate aspects as particularly helpful.

Some users reported that their initial attempts at delivering live online teaching at the start of lockdown, largely consisted of replicating the approach used in face-to-face (F2F) classes, requiring them to use their own judgements as to what would work well in supporting learning in an online environment, with less attention paid to engaging students through active and interactive learning and collaboration. PATTERNS? appeared to be helpful in avoiding such practices, with users reporting that they were able to use PATTERNS? as a checklist of important considerations when designing and delivering live sessions online, supporting an intentional approach to online instructional design and delivery. Users also reported that PATTERNS? was easy to remember due to its mnemonic qualities.

\section{Recommendations}

An important strength of PATTERNS? is its checklist-type quality, enabling important UDL pedagogic characteristics relating to engagement, such as active and interactive learning, collaboration and choice, to be intentionally designed into live online sessions. Effective implementation of such practices, especially collaboration, can be challenging when teaching online (Sandars et al., 2020). Hence, intentional learning design, in which opportunities to maximise student engagement, collaboration and activity are intentionally designed into teaching, appears to be an important factor in the effective delivery of online education (Major, 2014; Dunkle and Yantz, 2020; O'Keefe et al., 2020; Sandars et al., 2020), bridging the gap between emergency remote instruction and online learning (Kozimor, 2020). Such considerations may be especially important in relation to 
attenuating critical barriers to effective online learning such as social interaction (Shawaqfeh et al., 2020; Shrivastava et al., 2021), which is especially challenging when students learn at a physical distance (Singh, 2018; Aguilera-Hermida, 2020).

Subsequently, PATTERNS? appears to support an intentional approach that is more consistent with deliberate online learning than emergency remote instruction (Kozimor, 2020), with potential benefits for social interaction through increasing opportunities to embed important UDL characteristics including engagement, collaboration and activity. In terms of recommendations, when teaching in a virtual environment, colleagues should strive to use approaches that support carefully constructed, deliberate online instruction, rather than recreating unchanged F2F teaching practices in digital format. PATTERNS? represents such an approach.

A second strength of PATTERNS? is its mnemonic qualities. Mnemonics support the quick organisation of information, which can enhance learning and subsequent recall, as well as prompt and guide learners to employ explicit strategies (CAST, 2018; Conderman, 2020). Intentionally designing important pedagogic characteristics into teaching is undoubtedly made easier by following an explicit strategy like PATTERNS? Hence, the mnemonic quality of PATTERNS? may be central to its usefulness when intentionally planning the transition to live online teaching.

According to the Centre for Applied Special Technology (CAST, 2018), mnemonics support maximisation of the generalisability and transfer of learning, featuring prominently in their UDL Guidelines (2018). Colleagues are required to generalise and transfer the information in PATTERNS? into their own teaching contexts, which they have managed successfully, demonstrating another key benefit of the mnemonic approach.

In terms of recommendations, if teaching is to be transitioned from F2F to live online quickly, then a mnemonic such as PATTERNS? can support staff to effectively embed important UDL pedagogic characteristics into their live online teaching in multiple contexts. 


\section{References}

Aguilera-Hermida, A.P. (2020) 'College students' use and acceptance of emergency online learning due to COVID-19', International Journal of Educational Research Open, 1, p.100011. Available at: https://doi.org/10.1016/j.ijedro.2020.100011 (Accessed: 9 August 2021).

Biggs, J.B. (2011) Teaching for quality learning at university: What the student does. $4^{\text {th }}$ edn. New York: McGraw-Hill Education.

CAST (2018) Universal Design for Learning Guidelines version 2.2. Available at: http://udlguidelines.cast.org (Accessed: 9 August 2021).

Conderman, G. (2020) 'Mnemonics: a fun and effective way to remember', Kappa Delta Pi Record, 56(3), pp.139-142. Available at:

https://doi.org/10.1080/00228958.2020.1770008 (Accessed: 9 August 2021).

Dunkle, K.M. and Yantz, J.L. (2020) 'Intentional design and implementation of a "flipped" upper division geology course: improving student learning outcomes, persistence, and attitudes', Journal of Geoscience Education, 69(1), pp.55-70. Available at: https://doi.org/10.1080/10899995.2020.1787808 (Accessed:9 August 2021).

Kozimor, M.L. (2020) 'Editor's comment: three teaching takeaways from the COVID-19 pandemic', Teaching Sociology, 48(3), pp. 181-183. Available at: https://doi.org/10.1177/0092055X20931953 (Accessed: 9 August 2021).

Major, C.H. (2014) Teaching online: a guide to theory, research and practice. Baltimore: John Hopkins University Press.

O'Keefe, L., Rafferty, J., Gunder, A. and Vignare, K. (2020) 'Delivering high-quality instruction online in response to COVID-19: faculty playbook', Online Learning Consortium. Available at: http://olc-wordpress-

assets.s3.amazonaws.com/uploads/2020/05/Faculty-Playbook Final-1.pdf

(Accessed: 9 August 2021).

Journal of Learning Development in Higher Education, Issue 22: Compendium ～October 20216 
Rose, D. (2000) 'Universal design for learning', Journal of Special Education Technology 15(3), pp.45-49. Available at: https://doi.org/10.1177/016264340101600208 (Accessed: 9 August 2021).

Sandars, J., Correia, R., Dankbaar, M., De Jong, P., Goh, P.S., Hege, I., Masters, K., Oh, S.Y., Patel, R., Premkumar, K. and Webb, A. (2020) 'Twelve tips for rapidly migrating to online learning during the COVID-19 pandemic', MedEdPublish, 9, pp.1-13. Available at: https://doi.org/10.15694/mep.2020.000082.1 (Accessed: 9 August 2021).

Schneider, J.L., Ruder, S.M. and Bauer, C.F. (2018) 'Student perceptions of immediate feedback testing in student centered chemistry classes', Chemistry Education Research and Practice, 19(2), pp.442-451. Available at: https://doi.org/10.1039/C7RP00183E (Accessed: 9 August 2021).

Shawaqfeh, M.S., Al Bekairy, A.M., Al-Azayzih, A., Alkatheri, A.A., Qandil, A.M., Obaidat, A.A., Al Harbi, S. and Muflih, S.M. (2020) 'Pharmacy students perceptions of their distance online learning experience during the COVID-19 pandemic: a crosssectional survey study', Journal of Medical Education and Curricular Development, 7(1), pp.1-9. Available at: https://doi.org/10.1177/2382120520963039 (Accessed: 9 August 2021).

Shrivastava, G., Ovais, D., and Arora, N. (2021) 'Measuring the walls of communication barriers of students in higher education during online classes', Journal of Content, Community and Communication, 13(7), pp. 263-272: Available at: https://www.amity.edu/gwalior/jccc/pdf/jun 22.pdf (Accessed: 9 August 2021).

Singh, M. (2018) 'Value of face-to-face interactions between clinician-educators and patients or students to improve health care education', JMIR human factors, 5(2), p.e15. Available at: https://dx.doi.org/10.2196\%2Fhumanfactors.9859 (Accessed: 9 August 2021). 


\section{Author details}

Kevin L. Merry is the Head of Academic Development at De Montfort University. An award winning teacher, Kevin has a number of research interests including learning for mastery, Universal Design for Learning (UDL), instructional design, and emotional intelligence in learning and teaching. 